\title{
USING EXPERIMENTAL PLANNING TO OPTIMIZE THE HYDROLYSIS OF SUGAR CANE BAGASSE INTO FERMENTABLE SUGARS FOR BIOETHANOL PRODUCTION BY FUNGAL ENZYME MIXTURE
}

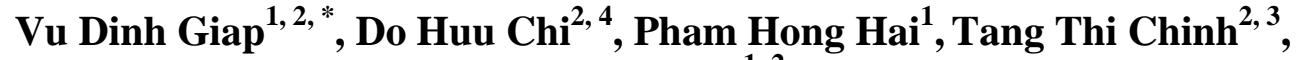 \\ Do Huu Nghi, 2 \\ ${ }^{1}$ Institute of Natural Products Chemistry, VAST, 18 Hoang Quoc Viet, Cau Giay, Hanoi \\ ${ }^{2}$ Graduate University of Science and Technology, VAST, 18 Hoang Quoc Viet, Cau Giay, Hanoi \\ ${ }^{3}$ Institute of Environmental Technology, VAST, 18 Hoang Quoc Viet, Cau Giay, Hanoi \\ ${ }^{4}$ Institute of Biotechnology, VAST, 18 Hoang Quoc Viet, Cau Giay, Hanoi \\ "Email: giapvudinh@gmail.com
}

Received: 20 October 2016; Accepted for publication: 13 May 2017

\begin{abstract}
In this study, the unpretreated sugar cane bagasse was milled to a particle size of $0.5-1$ $\mathrm{mm}$ and be used as material for bioconversion into fermentable sugars by using an enzyme cocktail acted synergistically. Experimental planning was used to optimize the enzyme conversion through assessment and analysis of individual parameter. As the result, the optimal condition for enzymatic conversion of sugar cane bagasse into reducing sugar product are at $\mathrm{pH}=5,40{ }^{\circ} \mathrm{C}$, and $48 \mathrm{~h}$ incubation in rate of enzyme (Cell/Xyl, AltFAE, XpoAE) and substrate (bagasse meal) is 3.1. From the above application, the mathematical model is found to describe equation of the bioconversion of bagasse into reducing sugars:

$$
\hat{y}=206.946+29.954 \mathrm{x}_{1}+5.501 \mathrm{x}_{2}+7.323 \mathrm{x}_{3}+2.288 \mathrm{x}_{2} \mathrm{x}_{3}-7.011 x_{1}^{2}
$$

and using flexible algorithm of nonlinear planning to identify optimal conditions of enzyme mixture of conversion into reducing sugars that the reaction reached $\hat{y} \max =251.86 \mathrm{mg}$ per gram bagasse with $\mathrm{x}_{1}=1.215, \mathrm{x}_{2}=1.215, \mathrm{x}_{3}=1.215$ or Cell/ $\mathrm{Xyl}=1 \mathrm{ml}(100 \mathrm{U})$, AltFAE $=0.5$ $\mathrm{ml}(7.56 \mathrm{U}), \mathrm{XpoAE}=0.4 \mathrm{ml}(10.8 \mathrm{U})$ on the test range. Experimental verification has the same result in constant conditons and reached total reducing sugars of $260.2 \mathrm{mg}$ per gram substrate.

Keywords: carbohydrate esterase, cellulase, lignocellulose bioconversion, bioethanol.

\section{INTRODUCTION}

Using the agro-industrial by-products that rich of lignocellulose to produce bioethanol has been studied extensively for decades [1]. These include sawdust, straw, bagasse, corn stover etc.
\end{abstract}


which is the most popular components of lignocellulosic biomass in Vietnam. Bagasse is a popular by-product in Asian countries, about 170 million tons/year, and has been known as useful material for bioethanol production. The main components of bagasse are cellulose (40\%), hemicelluloses $(26 \%)$ and about $20 \%$ lignin $[2,3]$.

The filamentous fungi have an efficient catalytic enzyme system to decompose lignocellulose. The enzymes that destroy the cell wall are attended because they produce a quality of sugar units that are necessary for fermentation and bioethanol production from rich lignocellulose materials [2]. Some enzymes such as cellulolytic enzyme system in which endo1,4-glucanase (EC 3.2.1.4) is responsible for swelling or hydration bond of the cellulose chains, exo-1,4-glucanase (EC 3.2.1.91), $\beta$-1,6-glucosidase (EC 3.2.1.21) hydrolyze bond of external circuit and release glucose. Hydrolytic enzymes carbohydrate esterase (CE) including acetyl esterase (EC 3.1.1.6), feruloyl esterase (EC 3.1.1.73) attack the branched polysaccharide of cell wall to break the links between xylan and lignin and separate the lignin from the structure of lignocelluloses. They play an important role in the first phase of lignocellulose hydrolysis [3, 4, $5]$.

However, application of microorganisms as a source of biological catalysts to hydrolyze byproducts of - agricultures into fermentable sugars is increasingly interested. This solution did not waste human food that follow environmentally friendly agro by-products treatment and can produce biofuel on a large scale through high performance and cost reduction.

The present application of mathematical models in the assessment and analysis to select the optimum parameters for metabolism is increasingly interested. Experimental planning is the method that select the number of experiments, necessary and sufficient conditions of the experiments can solve the tasks correctly, collect mathematical methods of treat empirical results. Based on the optimal points in space and linear coordinate transformation, disadvantages of classical regression analysis can be overcome. It reduces the number of experiments, receive more accurate information so the effect of experiment will be improved [6].

In this article, we used experimental planning to find mathematical model and optimal conditions for conversion of bagasse into fermentable sugars through enzymatic hydrolysis.

\section{MATERIALS AND METHODS}

\subsection{Materials}

Sugar cane bagasse that is the material for conversion need to be dried, grinded and screened (0.5 - $1.0 \mathrm{~mm}$ size) (Fig.1). In this study, we use raw bagasse that was not treated by chemical methods.

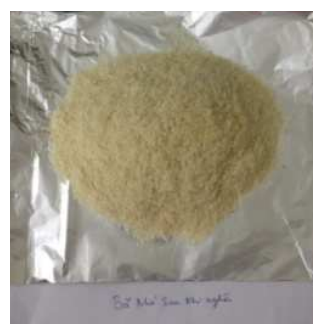

Figure 1. Sugar cane bagasse after grinding. 
Hydrolytic enzymes were purified from different fungi in previous studies:

- Enzyme feruloyl esterase (AltFAE) and acetyl esterase (XpoAE) were purified from Alternaria tenuissima [7] and Xylaria polymorpha [8] in enzyme activity at $11.2 \mathrm{Umg}^{-1}$ (total activity: $151.2 \mathrm{U}), 13.1 \mathrm{Umg}^{-1}$ (270.0U) respectively.

- Commercial enzymes were purified from Trichoderma reesei (carboxymethyl cellulase and glucuronoxylanase; Cell/Xyl, 1000-1600Ug ${ }^{-1}, \mathrm{AB}$ Enzyme, Darmstadt, Germany) [9].

\subsection{Methods}

\subsubsection{Estimation of reducing sugars by 3,5-dinitrosalicylic acid method (DNS)}

This method is based on a color reaction between reducing sugars with 3,5-dinitrosalicylic acid reagent (DNS). Color intensity of the reaction mixture is proportional to the concentration of reducing sugar within a certain range. Colorimetric is measured at $540 \mathrm{~nm}$. Based on the calibration curve graph of pure glucose with DNS reagent it will calculate a reducing sugar content of the sample [10].

Glucose calibration curve graph is constructed from optical density (OD) of a standard glucose solution with concentration at $0.1 ; 0.2 ; 0.3 ; 0.4 ; 0.5 ; 0.6(\mathrm{mg} / \mathrm{ml})$ respectively. OD of the range of standard solution and relationship between glucose concentration and absorbance is shown in Figure 2.

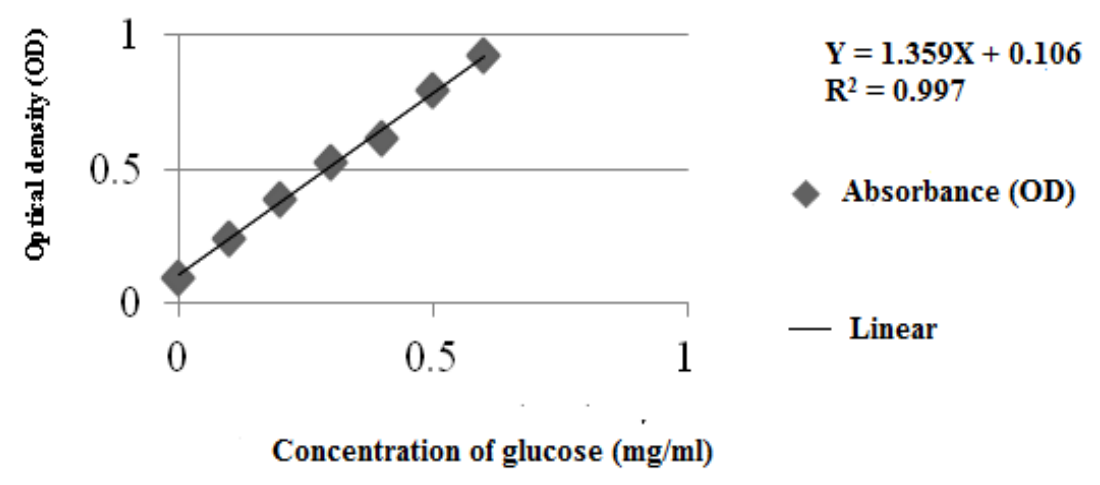

Figure 2. Glucose standard curve.

\subsubsection{Hydrolysis reaction of bagasse by enzymatic mixture}

Raw bagasse was incubated with purified enzymes from fungi including AltFAE (11.2 Umg$\left.{ }^{1}\right)$, XpoAE (13.1 $\mathrm{Umg}^{-1}$ ) and commercial enzymes were purified from Trichoderma reesei (Cell/Xyl). The reaction was implemented in $100 \mathrm{mM}$ MOPS buffer ( $\mathrm{pH}$ 5.5) compared with control sample in which the enzymes was inactivated by boiling at $95{ }^{\circ} \mathrm{C}$ for 30 minutes. After reactions were done total reducing sugars are determined 3,5-dinitrosalicylic acid method (DNS).

\subsubsection{Experimental planning method}

Experimental planning (active experiment) is the selection procedure of the number of experiments, necessary and sufficient conditions of the experiments that can solve the tasks 
correctly, collecting mathematical methods of to treat empirical results. Based on the optimal points in space and linear coordinate transformation, disadvantages of classical regression analysis can be overcome (Passive experiment, each variable is changed respectively). It reduces the number of experiments, receives more accurate information so the effect of experiment will be improved (educe time scales, effort, and cost of testing) [12]. This method use a seconddegree polynomial model (Box - Wilson) [6,11], based on experiment, they carry out additional tests towards the optimization (approximation) or based on data analysis, they use a seconddegree polynomial model (Box - Wilson). In this case, the regression takes the following form:

$$
\hat{y}=b_{\mathrm{o}}+\sum_{j=1}^{k} \mathrm{~b}_{\mathrm{j}} \mathrm{x}_{\mathrm{j}}+\sum_{u, j=1}^{k} \mathrm{~b}_{\mathrm{uj}} \mathrm{x}_{\mathrm{u}} \mathrm{x}_{\mathrm{j}}+\sum_{j=1}^{k} \mathrm{~b}_{\mathrm{jj}} \mathrm{x}_{j}^{2} \quad \mathrm{u} \neq \mathrm{j}
$$

In: $b_{o}-$ Free factors; $b_{j}-$ Linear effects; $b_{u j}-$ Double interactive effects; $b_{j j}-$ Squared effects.

\subsection{Design of experiment}

\section{Description of the process}

Research on the fermentation using hydrolysis of enzymatic mixture with effect factors: time $(\mathrm{h})$, temperature $\left({ }^{0} \mathrm{C}\right), \mathrm{pH}$, substrate volume (gram), enzyme volume $(\mathrm{ml})$ corresponding with enzyme activity (U) AltFAE, XpoAE, Cell/Xyl.

Parameter optimization was determined by reducing sugar content (mg per gram substrate). In the bagasse hydrolysis (substrate), the formed glucose concentration entirely depends on the above factors. By examining some factors affecting fermentation such as time, temperature, $\mathrm{pH}$, substrate volume, they will fix the factors to be optimized based on three parameters of three enzyme volumes that take part in hydrolysis in an appropriate range. Finally, they will find the optimal efficiency for substrate hydrolysis by describing a statistical experimental model that is compatible with empirical results.

\section{Experiment}

Applying the experimental planning method for bagasse hydrolysis, design experiments between grinding bagasse that change content from 0.4 to 0.8 gram and variable hydrolase volume within a range: Cell/Xyl $0.45 \mathrm{ml}-1.0 \mathrm{ml}$; AltFAE $0.12-0.7 \mathrm{ml}$; XpoAE $0.14-0.6 \mathrm{ml}$. Temperature range changes between $35{ }^{\circ} \mathrm{C}$ to $45{ }^{\circ} \mathrm{C}, \mathrm{pH} 4.5-5.5$, time $24-72 \mathrm{~h}$. All experiments are run in triplicate, the result of reducing sugar content determined by DNS method is the average of three independent experiments.

\section{RESULTS AND DISCUSSION}

\subsection{Applying the experimental planning method for sugar cane bagasse hydrolysis to form reducing sugars}

Experimenting to select the time, temperature, $\mathrm{pH}$ of the conversion of bagasse to form reducing sugar and choose the maximum value in each independent experiment, experiment results are shown in Table 1.

In Table 1, at the first 24 hour incubation (experiments $1-5$ ), the total formed reducing sugar content is $170.5 \mathrm{mg}$ per gram substrate. The reducing sugar content in the solution depends 
on many factors at this phase, new substrate, activity of three hydrolase play the most important part of reaction. There are lots of vulnerable structures of substrate and no inhibitors of enzyme activity. Hydrolase system (Cell/Xyl, feruloyl esterase (AltFAE) and acetyl esterase (XpoAE)) used a large number of cellulose derived from hydrolysis by debrandching enzymes (AltFAE and XpoAE) and there are more and more total reducing sugar formed. This is the phase that glucose molecule were formed most rapidly and highly during the whole reaction.

Table 1. Factors affecting the reducing sugar content in reaction.

\begin{tabular}{|c|c|c|c|c|c|c|c|c|c|}
\hline $\mathrm{N}^{0}$ & $\begin{array}{l}\text { Time } \\
\text { (h) }\end{array}$ & $\mathrm{pH}$ & $\begin{array}{c}\text { Temperature } \\
\left({ }^{\circ} \mathrm{C}\right)\end{array}$ & $\begin{array}{l}\text { Substrate } \\
\text { (gram) }\end{array}$ & $\begin{array}{l}\text { Cell/Xyl } \\
(\mathrm{ml})\end{array}$ & $\begin{array}{l}\text { AltFAE } \\
\quad(\mathrm{ml})\end{array}$ & $\begin{array}{l}\text { XpoAE } \\
(\mathrm{ml})\end{array}$ & $\begin{array}{l}\text { Enzyme/Substrate } \\
\text { Ratio } \\
\text { (ml/gram substrate) }\end{array}$ & $\begin{array}{c}\text { Total } \\
\text { Reducing } \\
\text { Sugars } \\
\text { (mg/gram } \\
\text { substrate) }\end{array}$ \\
\hline 1 & 24 & 5 & 40 & 0.4 & 0.5 & 0.3 & 0.2 & 2.5 & 170.5 \\
\hline 2 & 36 & 5 & 40 & 0.4 & 0.5 & 0.3 & 0.2 & 2.5 & 189.3 \\
\hline 3 & 48 & 5 & 40 & 0.4 & 0.5 & 0.3 & 0.2 & 2.5 & 198.2 \\
\hline 4 & 60 & 5 & 40 & 0.4 & 0.5 & 0.3 & 0.2 & 2.5 & 201.3 \\
\hline 5 & 72 & 5 & 40 & 0.4 & 0.5 & 0.3 & 0.2 & 2.5 & 203.4 \\
\hline 6 & 48 & 4.5 & 40 & 0.4 & 0.5 & 0.3 & 0.2 & 2.5 & 178.4 \\
\hline 7 & 48 & 5 & 40 & 0.4 & 0.5 & 0.3 & 0.2 & 2.5 & 198.2 \\
\hline 8 & 48 & 5.5 & 40 & 0.4 & 0.5 & 0.3 & 0.2 & 2.5 & 180.3 \\
\hline 9 & 48 & 5 & 35 & 0.4 & 0.5 & 0.3 & 0.2 & 2.5 & 160.9 \\
\hline 10 & 48 & 5 & 37 & 0.4 & 0.5 & 0.3 & 0.2 & 2.5 & 167.4 \\
\hline 11 & 48 & 5 & 40 & 0.4 & 0.5 & 0.3 & 0.2 & 2.5 & 198.2 \\
\hline 12 & 48 & 5 & 42.5 & 0.4 & 0.5 & 0.3 & 0.2 & 2.5 & 165.3 \\
\hline 13 & 48 & 5 & 45 & 0.4 & 0.5 & 0.3 & 0.2 & 2.5 & 134.5 \\
\hline 14 & 48 & 5 & 40 & 0.4 & 0.5 & 0.3 & 0.2 & 2.5 & 198.2 \\
\hline 15 & 48 & 5 & 40 & 0.6 & 0.5 & 0.3 & 0.2 & 1.7 & 201.4 \\
\hline 16 & 48 & 5 & 40 & 0.8 & 0.5 & 0.3 & 0.2 & 1.3 & 176.7 \\
\hline 17 & 48 & 5 & 40 & 0.4 & 0.5 & 0.3 & 0.2 & 2.5 & 198.2 \\
\hline 18 & 48 & 5 & 40 & 0.4 & 0.75 & 0.3 & 0.2 & 3.1 & 223.8 \\
\hline 19 & 48 & 5 & 40 & 0.4 & 1.0 & 0.3 & 0.2 & 3.8 & 225.1 \\
\hline 20 & 48 & 5 & 40 & 0.4 & 0.5 & 0.3 & 0.2 & 2.5 & 198.2 \\
\hline 21 & 48 & 5 & 40 & 0.4 & 0.5 & 0.5 & 0.2 & 3.0 & 214.1 \\
\hline 22 & 48 & 5 & 40 & 0.4 & 0.5 & 0.7 & 0.2 & 3.5 & 214.7 \\
\hline 23 & 48 & 5 & 40 & 0.4 & 0.5 & 0.3 & 0.2 & 2.5 & 198.2 \\
\hline 24 & 48 & 5 & 40 & 0.4 & 0.5 & 0.3 & 0.4 & 3.0 & 215.5 \\
\hline 25 & 48 & 5 & 40 & 0.4 & 0.5 & 0.3 & 0.6 & 3.5 & 216.7 \\
\hline
\end{tabular}

From 24 to 48 hours incubation, the rate of reaction would be regressive, glucose concentration and efficiency would grow slowly (198.2 mg per gram substrate). In this phase, 
the formed glucose will restrain enzyme activity, the number of cellulose branch form was released more slowly. On the other hand, enzyme activity was reduced when they were restricted for a while, some enzymes were trapped inside the porous structure of cellulose.

From $48 \mathrm{~h}$ until the reactions were finished after $72 \mathrm{~h}$, the total reducing sugar increased little from 198.2 to $203.4 \mathrm{mg}$ per gram substrate. No reaction can operate at 100 percent efficiency or there is unable to hydrolyze all of cellulose in bagasse. The enzymatic hydrolysis is a heterogeneous reaction, exposure phase plays an important role [4]. Due to the compact structure of lignocellulose, it is difficult for enzyme to penetrate into the fiber, enzyme cannot attack and hydrolyze these parts. As a result, the time that need to convert is about 48 hours incubation.

If there was a temperature rise $\left(35-40^{\circ} \mathrm{C}\right)$, the initial reaction rate would grow (experiments 9 - 13) the total reducing sugar increased from 160.9 to $198.2 \mathrm{mg}$ per gram substrate. The maximum initial reaction rates of hydrolysis are at $40{ }^{\circ} \mathrm{C}$. But the temperature continuously run up (from $40{ }^{\circ} \mathrm{C}$ to $45^{\circ} \mathrm{C}$ ), initial reaction rate slowed down and the total reducing sugar reduced to $134.5 \mathrm{mg}$ per gram substrate. Effect of $\mathrm{pH}$ on reaction rate of hydrolysis, the rate of enzymatic reaction increased with temperature, however, up to certain temperature, there was a decrease in the reaction rate down to zero. Because enzymes are proteins, the enzyme will be inactivated at a certain temperature.

As the $\mathrm{pH}$ increased from 4.5 to 5.0, the total reducing sugar increased from 178.4 to 198.2 mg per gram substrate (experiments $6-8$ ), but in contrast, when the $\mathrm{pH}$ increased from 5.0 to 5.5, the total reducing sugar decreased from 198.2 to $180.3 \mathrm{mg}$ per gram substrate.

Effect of $\mathrm{pH}$ on hydrolysis of each enzyme will work at its best within a certain range of $\mathrm{pH}$ values. The range for $\mathrm{pH}$ is 4.0 to 5.0 for enzyme preparation of Cell/Xyl, 4.5 to 5.5 for carbohydrate enzymes (AltFAE và $X p o A E$ ). Therefore, the $\mathrm{pH}=4.5$ has been chosen as the best value to perform hydrolysis.

The experiments 17-25 conducted a preliminary survey in a range of varying volume fraction of each enzyme joining in reaction process to find the orthogonal model showed the interaction between three hydrolases.

Only in using three hydrolases which we selected substrate concentration of second-degree polynomial model (Box - Wilson), the point of 0.6 gram $(4.8 \% \mathrm{w} / \mathrm{v})$ substrate (bagasse) is reliable when concentration of three enzymes (Cell/Xyl, AltFAE and XpoAE) was at a high value shown in experiments $14-16$. However, the fixed elements include 48 hour incubationperiod fermentation, $\mathrm{pH}=5.0$ and $40{ }^{\circ} \mathrm{C}$ temperature. By examining effect of some fermentation parameters such as time, temperature, $\mathrm{pH}$, substrate concentration to fix the above parameters, we would optimize three-enzyme volume which they joined in a compatible range of hydrolysis (each enzyme volume based on the dilution factor that was converted to activity $U$ respectively). Since we would find the optimum of bagasse hydrolysis based on the description statistical experimental model that was compatible with experimental results.

The second-degree polynomial model (Box - Wilson) will survey the effect of three hydrolases. Selecting the range of varying enzyme volume Cell/Xyl (E1), AltFAE (E2), XpoAE (E3)) will be seen in Table 2 .

Additional experiments to calculate the variance regeneration was executed at $\mathrm{t}=48 \mathrm{~h}$ incubation, $\mathrm{pH}=5.0, \mathrm{t}=35^{\circ} \mathrm{C}$, used 0.4 gram substrate and corresponding enzyme volume used for $\mathrm{Cell} / \mathrm{Xyl}=0.5 \mathrm{ml}(50 \mathrm{U}), A l t \mathrm{FAE}=0.3 \mathrm{ml}(4.53 \mathrm{U}), X p o \mathrm{AE}=0.2 \mathrm{ml}(5.4 \mathrm{U})$ and the total reducing sugar resulted respectively as $162.2 ; 159.3 ; 161.2 \mathrm{mg}$ per gram substrate. 
Using FORTRAN algorithm reached:

$$
\begin{gathered}
S_{t \mathrm{~s}}^{2}=2.17 \text { with } \mathrm{f}_{2}=2 ; \\
S_{b_{0}}=0.3804 ; \quad S_{b_{j}}=0.4451 ; \quad S_{b_{\mathrm{uj}}}=0.5028 ; \quad S_{b_{\mathrm{jj}}}=0.7054 .
\end{gathered}
$$

Table 2. The second-degree polynomial model (Box - Wilson).

\begin{tabular}{|l|c|c|c|c|c|}
\hline Enzyme & -1.215 & -1 & 0 & +1 & +1.215 \\
\hline Cell/Xyl & 0.4 & 0.45 & 0.7 & 0.95 & 1.0 \\
\hline XpoAE & 0.1 & 0.12 & 0.25 & 0.38 & 0.4 \\
\hline AltFAE & 0.1 & 0.14 & 0.3 & 0.46 & 0.5 \\
\hline
\end{tabular}

Table 3. Regression coefficients value t.

\begin{tabular}{|c|c|c|c|c|c|c|c|c|c|c|}
\hline \multirow{2}{*}{$\mathrm{b}_{\mathrm{j}}$} & $\mathrm{b}_{0}$ & $\mathrm{~b}_{1}$ & $\mathrm{~b}_{2}$ & $\mathrm{~b}_{3}$ & $\mathrm{~b}_{12}$ & $\mathrm{~b}_{13}$ & $\mathrm{~b}_{23}$ & $\mathrm{~b}_{11}$ & $\mathrm{~b}_{22}$ & $\mathrm{~b}_{33}$ \\
\cline { 2 - 11 } & 206.946 & 29.954 & 5.501 & 7.323 & -0.762 & -1.212 & 2.288 & -7.011 & -1.561 & -2.34 \\
\hline \multirow{2}{*}{$\mathrm{t}_{\mathrm{j}}$} & $\mathrm{t}_{0}$ & $\mathrm{t}_{1}$ & $\mathrm{t}_{2}$ & $\mathrm{t}_{3}$ & $\mathrm{t}_{12}$ & $\mathrm{t}_{13}$ & $\mathrm{t}_{23}$ & $\mathrm{t}_{11}$ & $\mathrm{t}_{22}$ & $\mathrm{t}_{33}$ \\
\cline { 2 - 12 } & 544.02 & 67.2 & 12.36 & 16.45 & 1.46 & 2.33 & 4.39 & 9.94 & 2.21 & 3.32 \\
\hline
\end{tabular}

At $t_{p}(f)=t_{0.05}(2)=4.3$ coefficients that have $t_{j}<4.3$ are inefficient including $t_{12}, t_{13}, t_{22}, t_{33}$ (Table 3). After rejecting the nonsense regression coefficients, we have the regression equation:

$$
\hat{y}=206.946+29.954 \mathrm{x}_{1}+5.501 \mathrm{x}_{2}+7.323 \mathrm{x}_{3}+2.288 \mathrm{x}_{2} \mathrm{x}_{3}-7.011 x_{1}^{2}
$$

The values of $\hat{y}$ at experimental points are shown in Table 4 . The test of interoperability of model was followed by Fisher Standard.

Residual variance:

$$
s_{d u}^{2}=\frac{\sum_{i=1}\left(y_{i}-\hat{y_{i}}\right)^{2}}{N-l}=\frac{\sum_{i=1}^{15}\left(y_{i}-\hat{y_{i}}\right)^{2}}{15-6}=29.46
$$

and:

$$
F=\frac{s_{d u}^{2}}{s_{t s}^{2}}=\frac{29.46}{2.17}=13.58
$$

Use Fisher benchmark:

$$
F_{p}\left(\mathrm{f}_{1}, \mathrm{f}_{2}\right)=F_{0.05}(9.2)=19.3
$$

See:

$$
\mathrm{F}<F_{p}\left(\mathrm{f}_{1}, \mathrm{f}_{2}\right)
$$

So, the regression equation will be compatible with the experiment result. Experimental results from using a second - degree polynomial model (Box-Wilson) were shown in Table 4.

Next, we will find the optimization or the maximum value of the function $\hat{y}$

$\operatorname{Max} \hat{y}\left(\mathrm{x}_{1}, \mathrm{x}_{2}, \mathrm{x}_{3}\right)$ with the binding conditions: 


$$
\begin{aligned}
& -1.215 \leq x_{1} \leq 1.215 \\
& -1.215 \leq x_{2} \leq 1.215 \\
& -1.215 \leq x_{3} \leq 1.215
\end{aligned}
$$

\begin{tabular}{|c|c|c|c|c|c|c|c|c|c|c|c|c|}
\hline $\mathrm{N}^{0}$ & $\mathrm{x}_{\mathrm{o}}$ & $\mathrm{x}_{1}$ & $\mathrm{x}_{2}$ & $\mathrm{x}_{3}$ & $\mathrm{x}_{1} \mathrm{x}_{2}$ & $\mathrm{x}_{1} \mathrm{x}_{3}$ & $\mathrm{x}_{2} \mathrm{x}_{3}$ & $\mathrm{x}_{1}^{\prime}$ & $\mathrm{x}_{2}^{\prime}$ & $x_{3}^{\prime}$ & $\begin{array}{c}\mathrm{y} \\
(\mathrm{mg} / \mathrm{g})\end{array}$ & $\begin{array}{c}y \\
(\mathrm{mg} / \mathrm{g})\end{array}$ \\
\hline 1 & + & - & - & - & + & + & + & 0.27 & 0.27 & 0.27 & 153.6 & 159.44 \\
\hline 2 & + & + & - & - & - & - & + & 0.27 & 0.27 & 0.27 & 219.5 & 219.35 \\
\hline 3 & + & - & + & - & - & + & - & 0.27 & 0.27 & 0.27 & 160.4 & 165.87 \\
\hline 4 & + & + & + & - & + & - & - & 0.27 & 0.27 & 0.27 & 224.2 & 225.78 \\
\hline 5 & + & - & - & + & + & - & - & 0.27 & 0.27 & 0.27 & 164.8 & 169.52 \\
\hline 6 & + & + & - & + & - & + & - & 0.27 & 0.27 & 0.27 & 226.8 & 229.42 \\
\hline 7 & + & - & + & + & - & - & + & 0.27 & 0.27 & 0.27 & 181.7 & 185.09 \\
\hline 8 & + & + & + & + & + & + & + & 0.27 & 0.27 & 0.27 & 239.7 & 245.00 \\
\hline 9 & + & -1.215 & 0 & 0 & 0 & 0 & 0 & 0.745 & -0.73 & -0.73 & 163.4 & 163.54 \\
\hline 10 & + & +1.215 & 0 & 0 & 0 & 0 & 0 & 0.745 & -0.73 & -0.73 & 227.9 & 236.33 \\
\hline 11 & + & 0 & -1.215 & 0 & 0 & 0 & 0 & -0.73 & 0.745 & -0.73 & 195.9 & 193.25 \\
\hline 12 & + & 0 & +1.215 & 0 & 0 & 0 & 0 & -0.73 & 0.745 & -0.73 & 211.5 & 206.62 \\
\hline 13 & + & 0 & 0 & -1.215 & 0 & 0 & 0 & -0.73 & -0.73 & 0.745 & 192.3 & 191.04 \\
\hline 14 & + & 0 & 0 & +1.215 & 0 & 0 & 0 & -0.73 & -0.73 & 0.745 & 212.8 & 208.83 \\
\hline 15 & + & 0 & 0 & 0 & 0 & 0 & 0 & -0.73 & -0.73 & -0.73 & 210.2 & 206.95 \\
\hline
\end{tabular}

Table 4. Planning matrix and experimental results.

Experiment used flexible algorithm of nonlinear planning [6] that found $y$ max $=251.86$ mg per gram bagasse with $\mathrm{x}_{1}=1.215, \mathrm{x}_{2}=1.215, \mathrm{x}_{3}=1.215$ or Cell $/ \mathrm{Xyl}=1 \mathrm{ml}(100 \mathrm{U})$, AltFAE $=0.5 \mathrm{ml}(7.56 \mathrm{U}), X p o \mathrm{AE}=0.4 \mathrm{ml}(10.8 \mathrm{U})$, the ratio of enzyme (Cell/Xyl, AltFAE, XpoAE) and substrate (bagasse meal) are 3.1.

Table 5. Result of using a second-degree polynomial model (Box - Wilson).

\begin{tabular}{|c|c|c|c|c|c|}
\hline $\mathrm{N}^{0}$ & $\begin{array}{c}\text { Cell/Xyl } \\
(\mathrm{ml})\end{array}$ & $\begin{array}{c}\text { XpoAE } \\
(\mathrm{ml})\end{array}$ & $\begin{array}{c}\text { AltFAE } \\
(\mathrm{ml})\end{array}$ & $\begin{array}{c}\text { Enzyme/Substrate } \\
\text { Ratio (ml/gram) }\end{array}$ & $\begin{array}{c}\text { Total Reducing Sugars } \\
(\mathrm{mg} / \text { gram substrate })\end{array}$ \\
\hline 1 & 1 & 0.4 & 0.5 & 3.1 & 260.2 \\
\hline 2 & 1.1 & 0.4 & 0.5 & 3.3 & 260.7 \\
\hline 3 & 1.2 & 0.4 & 0.5 & 3.5 & 260.9 \\
\hline 4 & 1 & 0.5 & 0.5 & 3.3 & 258.7 \\
\hline 5 & 1 & 0.6 & 0.5 & 3.5 & 258.4 \\
\hline 6 & 1 & 0.7 & 0.5 & 3.6 & 255.8 \\
\hline 7 & 1 & 0.4 & 0.6 & 3.3 & 254.9 \\
\hline 8 & 1 & 0.4 & 0.7 & 3.5 & 254.1 \\
\hline 9 & 1 & 0.4 & 0.8 & 3.6 & \\
\hline
\end{tabular}


Results from Table 5 showed the degree of similarity between classical regression analysis and experimental planning. Total reducing sugars reached $251.86 \mathrm{mg}$ per gram substrate at $40{ }^{\circ} \mathrm{C}, \mathrm{pH}=5.0$, in 48 hours incubation in rate of enzyme (Cell/Xyl, AltFAE, XpoAE) and substrate (bagasse meal) is 3.1. The volume and enzyme activity respectively as follows: Cell $/ \mathrm{Xyl}=1.0 \mathrm{ml}(100 \mathrm{U}), A l t \mathrm{FAE}=0.5 \mathrm{ml}(7.56 \mathrm{U})$, XpoAE $=0.4 \mathrm{ml}(10.8 \mathrm{U})$. In the same conditions, the control result was $260.2 \mathrm{mg}$ reducing sugars. The experimental results also showed that in the range of varying concentrations between three hydrolases, the total reducing sugars was not only not increased but significantly decreased when the ratio of enzyme and substrate increased. Indeed, the amount of enzyme added, the reaction rate increases but increasing the enzyme concentration beyond a certain point, the substrate concentration becomes the limiting factor, and at the certain point, the reaction rate will not increase but decrease.

\section{CONCLUSION}

The result has identified optimal conditions for bioconversion of sugar cane bagasse into reducing sugars by mixed enzymes (Cell/Xyl, $A l t \mathrm{FAE}, X p o \mathrm{AE}$ ) at $40^{\circ} \mathrm{C}, \mathrm{pH}=5,48 \mathrm{~h}$ incubation with the ratio of enzyme (Cell/Xyl, AltFAE, XpoAE) and substrate (sugar cane bagasse meal) are 3.1. The applying the experimental planning method led to find the mathematical model that describe equation of the bioconversion of bagasse into reducing sugars: $\hat{y}=206.946+29.954 \mathrm{x}_{1}$ $+5.501 \mathrm{x}_{2}+7.323 \mathrm{x}_{3}+2.288 \mathrm{x}_{2} \mathrm{x}_{3}-7.011 x_{1}^{2}$. By using flexible algorithm of nonlinear planning we found the optimal conditions of enzyme mixture of conversion into reducing sugars that the reaction reached $\hat{y} \max =251.86 \mathrm{mg}$ per gram bagasse with $\mathrm{x}_{1}=1.215, \mathrm{x}_{2}=1.215, \mathrm{x}_{3}=1.215$ or Cell $/ \mathrm{Xyl}=1 \mathrm{ml}(100 \mathrm{U}), A l t \mathrm{FAE}=0.5 \mathrm{ml}(7.56 \mathrm{U})$, XpoAE $=0.4 \mathrm{ml}(10.8 \mathrm{U})$ on the test range. Experimental verification has the same result in constant conditions and reached total reducing sugars of $260.2 \mathrm{mg}$ per gram substrate.

Acknowledgement: This work is supported by a grant from the National Foundation for Science and Technology Development (NAFOSTED, No. 106-NN.02-2013.44).

\section{REFERENCES}

1. Diep N. Q.. Fujimoto S.. Minowa T.. Sakanishi K. and Nakagoshi N. - Estimation of the potential of rice straw for ethanol production and the optimum facility size for different regions in Vietnam. Appl. Energ. 93 (2012) 205-211.

2. Muhammad Zam Khan. - The enzymatic hydrolysis and fermentation of pretreated wheat straw and bagasse to ethanol. ATDF Journal 2 (2) (2010) 29-35.

3. Sun J. X. and Sun R. C. - Isolation and characterization of cellulose from sugarcane bagasse. Journal Polymer Degradation and Stability 84 (2) 331-339.

4. Hetti Palonen. - Role of lignin in the enzymatic hydrolysis of lignocellulose. VTT Biotechnology (2004) 11-39.

5. Jorgensen H., Bach Kristensen J. and Felby C. - Enzymatic conversion of lignocellulose into fermentable sugars: challenges and opportunities. Biofuel. Bioprod. Bior. 1 (2007) $119-134$. 
6. Nguyen Minh Tuyen - Experimental planning, Science and engineering publisher, Hanoi, 2007 (Vietnamese).

7. Do Huu Nghi, Vu Dinh Giap, Do Huu Chi, Nguyen Trung Hieu. - Feruloyl esterase from Alternaria tenuissima and antioxidant activity of enzymatic reaction products, Vietnam Medical Journal 445 (8) (2016) 143-148.

8. Nghi D. H., Ullrich R., Moritz F., Huong L. M., Giap V. D., Chi D. H., Hofrichter M. and Liers C. - The Ascomycete Xylaria polymorpha Produces an Acetyl Esterase That Solubilises Beech Wood Material to Release Water-soluble Lignin Fragments. Journal Korean Soc. Appl Biol. Chem. 58 (3) (2015) 415-521.

9. Do Huu Nghi, Vu Dinh Giap, Do Huu Chi, Tran Thi Nhu Hang, Tran Thi Hong Ha, Le Mai Huong. - Immobilization of cellulase from fungus trichoderma sp. on composite beads of chitosan and activated kaolin. Journal of Science and Technology 52 (5) (2014) 559-568.

10. Miller G. L. - Use of dinitrosalicylic acid reagent for determination of reducing sugar. Anal. Chem. 3 (1959) 426-428.

11. Pham Hong Hai, Ngo Kim Chi. - Data analyzing and experimental planning in science research, Science and Technology publisher, Hanoi, 2007 (Vietnamese).

12. David M. Himmelblau - Applied nonlinear programming. McGraw - Hill Book Company. 1972. 